\title{
Nation-Making at the Border: Zambian Diplomacy in the Democratic Republic of Congo
}

\author{
MILES LARMER \\ Universities of Oxford and Pretoria
}

\section{INTRODUCTION}

How were new African nations made in the moment of their decolonization? In what spaces can we usefully observe the process of nation-making? These questions were briefly the subject of contemporaneous analysis in Africa's independence moment in the late 1950s and early 1960s, but they have been surprisingly neglected ever since. ${ }^{1}$ A focus on state-building and the supposed limitations and weaknesses of African states has arguably led to a failure to examine how both political elites and their subjects imagined and sought to articulate the new nations they were making. ${ }^{2}$ Historians have, more recently, analyzed how states and a variety of political actors understood and articulated what it meant to be "Kenyan," "Ghanaian," or "Zambian" and who, and who did not, qualify as a national. ${ }^{3}$

Acknowledgments: This article is based on research that has received funding from the European Research Council (ERC) under the European Union's Horizon 2020 research and innovation program (grant agreement no: 681657: "Comparing the Copperbelt: Political Culture and Knowledge Production in Central Africa"). The author acknowledges the generous support of the ERC. Earlier versions were presented at the universities of Leipzig and Birmingham, and I am grateful for the critical comments I received at these events, particularly from Steffi Marung, and from the anonymous $C S S H$ reviewers. All helped me to significantly improve the article.

1 Thomas Hodgkin, Nationalism in Colonial Africa (London: Frederick Muller, 1956); James S. Coleman, "Nationalism in Tropical Africa," American Political Science Review 48, 2 (1954): 404-26.

2 Among the most influential studies of the African state are Jeffrey Herbst, States and Power in Africa (Princeton: Princeton University Press, 2000); Joel S. Migdal, Strong Societies and Weak States: State-Society Relations and State Capabilities in the Third World (Princeton: Princeton University Press, 1988); and J.-F. Bayart, The State in Africa: The Politics of the Belly (London: Longman, 1993).

3 For example, Jean Allman, The Quills of the Porcupine-Asante Nationalism in an Emergent Ghana (Madison: University of Wisconsin Press, 1993); Daniel Branch, Kenya: Between Hope and 
Focusing on the periphery rather than the center provides an important way of addressing such questions: African borders are stereotypically artificial and weak, cutting through preexisting societies and interacting uneasily with them. Imposing a sense of national identity in border regions with mixed and mobile populations, dynamic migrant flows, and cross-border linkages was a task fraught with contradiction, although not one qualitatively different from processes of post-imperial nation-making in much of the rest of the world in the nineteenth and twentieth centuries. ${ }^{4}$ This article does not seek to assess how effective such efforts were in asserting or imposing national identity, but instead explores what they reveal about the ideas and values that informed one set of state elites' assertions of what nations meant and their relationship to history, local identities, and moral codes regarding, among other things, customary authority and gendered behavior. In this I draw upon Bourdieu's insight that the state's involvement in the codification and legalization of national identity involved not only the assertion of state sovereignty over territorial space, but also the assertion of symbolic power, the right to classify, and the expression of moral and political notions that underlay ostensibly bureaucratic, disinterested state structures. ${ }^{5}$ By analyzing the attempts of officials of Zambia's new ruling party, state administrators, and diplomatic representatives to establish and assert their notion of Zambian-ness, the paper exposes both the fragility of new national identities and the extent to which elites sought to underpin them by asserting moral certainties.

Although Cooper has established that African borders and national identities were both fluid and contested during the late colonial period, it is still generally assumed that such contestation was rapidly curtailed in the

\footnotetext{
Despair, 1963-2011 (New Haven: Yale University Press, 2011); James Brennan, Taifa: Making Nation and Race in Urban Tanzania (Athens: Ohio University Press, 2012); Emma Hunter, Political Thought and the Public Sphere in Tanzania: Freedom, Democracy and Citizenship in the Era of Decolonization (New York: Cambridge University Press, 2015); Julie MacArthur, Cartography and the Political Imagination: Mapping Community in Colonial Kenya (Athens: Ohio University Press, 2016); Kate Skinner, The Fruits of Freedom in British Togoland: Literacy, Politics and Nationalism, 1914-2014 (New York: Cambridge University Press, 2015); Meredith Terreta, Nation of Outlaws, State of Violence: Nationalism, Grassfields Tradition and State Building in Cameroon (Athens: Ohio University Press, 2014); Miles Larmer, Rethinking African Politics: A History of Opposition in Zambia (Farnham: Ashgate, 2016 [2011]); Baz Lecocq, Disputed Desert: Decolonisation, Competing Nationalisms and Tuareg Rebellions in Northern Mali (Leiden: Brill, 2010); Justin Pearce, Political Identity and Conflict in Central Angola, 19752002 (Cambridge: Cambridge University Press, 2015).

${ }^{4} \mathrm{I}$ am grateful to John Breuilly for clarifying my thinking in this regard. For a sustained version of this argument, see Miles Larmer and Baz Lecocq, "Historicising Nationalism in Africa" (forthcoming in "Nations and Nationalism," 2018; https://onlinelibrary.wiley.com/doi/abs/10.1111/nana. 12448).

5 Pierre Bourdieu, "Codification," in In Other Words: Essays towards a Reflexive Sociology (Cambridge: Cambridge University Press, 2007 [1990]), 76-86.
} 
wake of independence itself. ${ }^{6}$ The test of such postcolonial contestation has often been an institutional one: disputed territorial claims, international recognition, and secessionist conflicts were notable for their general absence by the 1970s, following the Organisation of African Unity's endorsement of colonial borders as the sole basis for independent states. ${ }^{7}$ However, the construction and dissemination of new nations in the context of decolonization was only partly a matter of internationally recognized statehood. Formal independence and the recognition of colonial borders as national borders were certainly important aspects of a legal framework that made (or unmade) many people's status as citizens or strangers. Recent studies, particularly those of Sara Dorman and Emma Hunter, have shown how notions of citizenship were deployed during and after Africa's decolonization, as a way in which both political elites and subaltern groups sought to define various national identities, to delegitimize population groups and/or political opponents as "foreign," and in other ways to assert politically contingent definitions of citizenship as normative for nation-states in the making. ${ }^{8}$ In this regard, this study will show how the Congolese state under President Mobutu responded to ongoing initiatives for secession and regional autonomy by redefining citizenship to exclude his political enemies. I will contrast this with the comparatively inclusive approach to citizenship followed by its southern neighbor Zambia. ${ }^{9}$

It is argued, however, that citizenship is only one element of a wider process of nation-making. As Dorman, Hammett, and Nugent state, "Nation building comprised a vocabulary, and sometimes a practice, of inclusion, but both implicitly and explicitly shaped assumptions about how members of the nation should live, behave and identify themselves." ${ }^{\prime 10}$ The important focus on overtly exclusionary citizenship claims may detract attention from more quotidian and/or ideational assertions of national identity. In this regard, state officials not only issued decrees defining who was and was not a "national": they sought through their activities and communications to articulate the appropriate relationship between nation-state institutions and the "people" and to define the latter in discursive, moralistic, and gendered norms. State officials,

${ }^{6}$ Frederick Cooper, Citizenship between Empire and Nation-Remaking France and French Africa, 1945-1960 (Princeton: Princeton University Press, 2014).

7 https://au.int/web/en/treaties/oau-charter-addis-ababa-25-may-1963 (accessed 25 Mar. 2017).

8 Sara Dorman, Daniel Hammett, and Paul Nugent, "Introduction: Citizenship and Its Casualties in Africa," in S. Dorman, D. Hammett, and P. Nugent, eds., Making Nations, Creating Strangers: States and Citizenship in Africa (Leiden: Brill, 2007); Emma Hunter, Political Thought and the Public Sphere: Freedom, Democracy and Citizenship in the Era of Decolonization (New York: Cambridge University Press, 2015); Emma Hunter, ed., Citizenship, Belonging and Political Community in Africa: Dialogues between Past and Present (Athens: Ohio University Press, 2016).

${ }^{9}$ Even in Zambia, though, exclusionary projects were initiated by some actors at the moment of independence: see Duncan Money's new analysis of the removal from mine employment of those rendered "non-Zambians" by political independence: “"Aliens' on the Copperbelt: Zambianization, Nationalism and Non-Zambian Africans in the Mining Industry" (2018, under review).

${ }^{10}$ Dorman, Hammett, and Nugent, "Introduction," 8. 
including diplomats, sought by such means to define both national identity in general and the national identity of their new nation-states in particular. This should, then, be understood as a simultaneously institutional, political, and discursive process involving unequal interactions between elites and subaltern actors. The practice of nation-making also involves the articulation and deployment (and the contestation) of supposedly national values and characteristics, resting on claims about a country's history and society, asserted in relation to its neighbors and commonly constituted, as Derek Peterson's work clearly demonstrates, in moral terms. ${ }^{11}$ The assertion of an inherent national character justified, in turn, a particular form of national independence and a nationbuilding project to be carried out within a "natural" set of borders. It was also a powerful means of delegitimizing, not only partition or secession (as in the Congolese case), but also, as in Zambia, even slight decentralization of a centralized state or contestation of a ruling party's hegemony.

The field of borderland studies has helpfully focused attention on the complex lived reality of cross-border communities, showing that the imposition of state authority at the border is an ongoing process involving both institutional and ideational work. ${ }^{12}$ Kate Skinner's history of nationalism in decolonizing Togoland establishes the potential for border polities to conceive of themselves as nations and assert themselves politically in ways that challenged the legitimacy of Ghanaian nation-statehood. ${ }^{13}$ If we widen our focus to border regions where nations were being made in opposition to their neighbors, where newly independent nation-states sought to turn mobile cross-border peoples into disciplined, rooted, national subjects, we can better appreciate the ways in which national identities were made in more quotidian, discursive forms.

Borders, it is widely acknowledged, are spaces where national identities are constructed and asserted in opposition to another. But at a local level, national identities are also moral constructions on which imagined communities rest. This remains a neglected aspect of the construction of African nationality, as does the extent to which new nations (re)asserted moral values in relation to, for example, citizenship, education, gender identities, and the interplay between urban and rural societies. ${ }^{14}$ Rogers Brubaker argues that the initial period of independent nationhood was, in France and Germany, formative for the adoption and shaping of such tropes of national identity. ${ }^{15}$ He conceives of citizenship as simultaneously liberating and exclusionary,

11 Derek R. Peterson, Ethnic Patriotism and the East African Revival (Cambridge: Cambridge University Press, 2012).

12 A seminal work for African borderland studies is P. Nugent and A. I. Asiwaju, eds., African Boundaries (Edinburgh: Edinburgh University Press, 1996).

13 Skinner, Fruits of Freedom.

14 Larmer and Lecocq, "Historicising Nationalism."

15 Rogers Brubaker, Citizenship and Nationhood in France and Germany (Cambridge: Harvard University Press, 1992). 
creating a "forced mobility" that contributes to global inequalities and, I would add, inequalities within nations and societies. Such assertions of citizenship in newly independent Africa were, as we will see, particularly pronounced when it came to the acquisition or denial of various resources - employment, education, and so on - that, as a result of independence, became increasingly tied to citizenship. The distribution of such resources was, therefore, commonly justified in morally constituted designations of "deserving" or "undeserving" citizens.

Zambia's new diplomats played an important and hitherto undocumented role in such distributions and designations. Whereas diplomatic representation was once conceived of in realist terms as the rational projection of state interests, the "new diplomatic history" has revealed that this diplomacy takes place in culturally and socially constructed spaces and involves the projection of cultural values by (usually) male actors. ${ }^{16}$ Recent histories of diplomacy, focusing on the attitudes and methods of networks and individuals, draw attention to the cultural context within which diplomats think and act, as well as the mutually constitutive relationship between foreign representation and domestic national identity. ${ }^{17}$ Peter Jackson has insightfully used Pierre Bourdieu's "structural constructivism" and the notion of "habitus" to explain foreign policy-making in terms of the relationship between cultural dispositions that inform the attitudes and actions of social actors and the structural contexts in which they develop and evolve. ${ }^{18}$ Bourdieu's concept of "codification" provides insight into the conditions in which societal rules were challenged and thrown into confusion by the upheavals of decolonization, necessitating the articulation and implementation of new codes of appropriate behavior ostensibly embedded in a combination of international law and national political culture: "Codification goes hand in glove with discipline and with the normalization of practices... Codification is an operation of symbolic ordering, or of the maintenance of the symbolic order, which is most often the task of the great state bureaucracies... Codification minimizes ambiguity and vagueness, in particular in interactions. It is particularly indispensable and just as efficient in situations in which the risks of collision, conflict and accident, hazard and chance ... are particularly important."19

Building on these insights, this article argues that Zambia's first generation of diplomatic representatives reflected and articulated a set of practices which they claimed were rooted in the social and cultural values of their

\footnotetext{
${ }_{17}$ For an overview, see http://newdiplomatichistory.org/about (accessed 30 Mar. 2017).

17 Geoffrey Roberts, "History, Theory and the Narrative Turn in IR," Review of International Studies 32, 4 (2006): 703-14; David Reynolds, "International History, the Cultural Turn and the Diplomatic Twitch," Cultural and Social History 3, 1 (2006): 75-91.

18 Peter Jackson, "Pierre Bourdieu, the 'Cultural Turn' and the Practice of International History," Review of International Studies 34, 1 (2008): 155-81.

19 Bourdieu, "Codification," 80.
} 
nation-in-the-making. In 1963-1964, officials of the United National Independence Party (UNIP), dispatched to Elisabethville to marshal electoral support among proto-Zambians abroad in pre-independence elections, asserted the identity and authority of a nation-state in the making. From 1964, diplomats of the newly independent state found new ways of asserting the Zambian nation, but encountered and were troubled by different notions of national belonging among members of cross-border Copperbelt societies. Both sets of officials sought to formalize and normalize a border region that was, in terms of this emergent national imaginary, at constant risk of "conflict and accident, hazard and chance."

\section{B A C K G R O UN D}

This article explores the establishment of Zambian political and diplomatic space in the Democratic Republic of Congo before and after the independence of Zambia (previously Northern Rhodesia) in October 1964. It focuses on Zambian political and diplomatic representatives in the southern Congolese city of Elisabethville in the early-to-mid 1960s. Elisabethville was until January 1963 the capital of the unrecognized state of Katanga, which seceded shortly after Congolese independence in June $1960 .^{20}$ The new Zambian government was formed by UNIP, which had strongly opposed the Katangese secession. Zambia's new diplomatic representatives, however, found themselves in a province recently governed by a secessionist government which, they discovered, retained strong residual support. This support was particularly significant among those who were now considered of "Zambian" ancestry, but whose presence in Katanga was the result of a centuries-long interaction of mineral extraction, migrant labor, and intertwined kinship. ${ }^{21}$

Despite attempts by the Congolese colonial state and mining companies to "indigenize" their subjects and workforce, tens of thousands of Katangese residents were inherently ambiguous in their relationship with one or both colonial identities, identities that had been imperfectly imposed by colonial states on a region characterized by societal identities and migratory flows that both straddled and took advantage of the border. Migrants from Bemba-speaking areas of Northern Rhodesia were prominent in the Katangese mine labor force, while the Lunda, whose once-powerful polity had been divided between Northern Rhodesia, Portuguese Angola, and the Belgian Congo, remained a cohesive society with chiefly authorities in all three territories, each recognizing the

\footnotetext{
${ }^{20}$ Lise Namikas, Battleground Africa: Cold War in the Congo 1960-1965 (Stanford: Stanford University Press, 2013); Miles Larmer and Erik Kennes, "Rethinking the Katangese Secession," Journal of Imperial and Commonwealth History 42, 4 (2014): 741-61.

21 Miles Larmer, "At the Crossroads: Mining and Political Change on the Katangese-Zambian Copperbelt," Oxford Handbooks Online (Oxford: Oxford University Press, 2016): http://www.oxfordhandbooks.com/view/10.1093/oxfordhb/9780199935369.001.0001/oxfordhb-9780199935369-e-20.
} 
ultimate authority of the Lunda king, the Mwaant Yav. ${ }^{22}$ Most Lunda had supported the secession and many Northern Rhodesian Bembas and Lundas had been employed by the Katangese state as civil servants. ${ }^{23}$

In representing their new state, Zambia's representatives drew on the precedents of their colonial predecessors. The British Consul General in Elisabethville had overseen British economic and political interests in Haut Katanga, an area of economic and strategic importance in which British capital was heavily invested. Its officers, including future Zambian Cabinet Secretary Valentine Musakanya, managed the panicked out-flow of Belgian settlers to Northern Rhodesia following Congo's post-independence violence in $1960 .{ }^{24}$ Consulate officials, in line with Britain's opposition to the forcible ending of the secession by United Nations' forces, were perceived as siding with the illegal state against the internationally recognized claim of Congo to Katangese territory. The settler-led government of the Central African Federation (CAF), in which Northern Rhodesia was incorporated from 1953-1963, was sympathetic to Tshombe, providing a safe haven from UN detention and a conduit for arms supplies. $^{25}$ Tshombe's government also provided financial aid to UNIP's political opponents, Harry Nkumbula's Northern Rhodesia African National Congress (NRANC). ${ }^{26}$ Despite the ending of the secession in January 1963, Katanga remained a place of tension and widespread opposition to the Congolese state. Matters were further complicated by the surprise appointment of Tshombe as Congolese Prime Minister in mid-1964; during his administration, Western-backed government forces ousted the leftist Simba rebels from Stanleyville and held parliamentary elections. In November 1965, however, Congo's post-independence political turmoil was ended by Joseph Mobutu's coup. $^{27}$

\section{WHAT WAS ZAMBIA?}

In the midst of these events, the Zambian nation-state was born. Zambians were relative latecomers to the process of making nations in colonial Africa.

\footnotetext{
22 Andrew Roberts, A History of the Bemba: Political Growth and Change in North-Eastern Zambia before 1900 (Madison: University of Wisconsin Press, 1973); Edouard Bustin, Lunda under Belgian Rule: The Politics of Ethnicity. Cambridge: Harvard University Press.

${ }^{23}$ Kennes and Larmer, The Katangese Gendarmes and War in Central Africa: Fighting Their Way Home (Bloomington: Indiana University Press, 2016), 43.

${ }^{24}$ Miles Larmer, ed., The Musakanya Papers: The Autobiographical Writings of Valentine Musakanya (Lusaka: Lembani Trust, 2010), 24-29.

${ }^{25}$ Matthew Hughes, "Fighting for White Rule in Africa: The Central African Federation, Katanga, and the Congo Crisis, 1958-1965," International History Review 25, 3 (2003): 596615, 603-8; Ian Colvin, The Rise and Fall of Moise Tshombe (London: Leslie Frewin, 1968), $111-17$.

${ }^{26}$ Giacomo Macola, Liberal Nationalism in Central Africa: A Biography of Harry Mwaanga Nkumbula (New York: Palgrave Macmillan, 2010), 84-87.

${ }^{27}$ Centre de Recherche et d'Information Socio-Politiques (hereafter CRISP), Congo 1965 (Brussels: CRISP, 1966), 340-87.
} 
Northern Rhodesia was, it has been argued, a colony of leftovers, its borders defined externally by more pressing initiatives to its north and south. ${ }^{28}$ The Barotse kingdom, under its agreement with Britain, retained significant legal autonomy within the colonial system under its king the Litunga. ${ }^{29}$ The assertion of Zambian nationhood was primarily a response to the integration of Northern Rhodesia into the Central African Federation in the early 1950s, a project that, African elites understood, threatened the further subordination of African interests to those of settlers, primarily in Southern Rhodesia. ${ }^{30}$ The urban focus of anti-colonialism in Northern Rhodesia-and the leading role played by Copperbelt- and Lusaka-based leaders - shaped UNIP discourse as it broke away from the NRANC in 1959. UNIP leader Kenneth Kaunda sought, like nationalists elsewhere, to mobilize his core supporters by linking their cultural outlook and socioeconomic concerns to the metanarrative of national independence. UNIP's vision of nationalism was - reflecting its core support base on the cosmopolitan Copperbelt and areas of Northern Rhodesia linked to it by migration and remittance flows - materialist, redistributive, socialistic in a form influenced by missionary Christianity, anti-“tribal", and unitary in its approach to nation-making. The party also acquired a reputation for youthful militancy: in 1961 its rural northern supporters, protesting constitutional proposals favorable to the racial status quo, engaged in direct action known as "Cha Cha Cha," involving attacks on government buildings, the blocking of roads, and the burning of bridges, to which the Northern Rhodesian state responded violently. ${ }^{31}$ Such actions angered chiefs in Luapula Province, some of whom aligned themselves with the Katangese secession. In April 1962, the Lunda chief, the Mwata Kazembe, met with Tshombe in Elisabethville: he expressed his support for the NRANC and suggested that Katangese residents should come to Northern Rhodesia so as to vote for UNIP opponents in forthcoming elections. The Mwata Kazembe, whose name was Paul Kanyembo, was himself a cross-border migrant, having previously lived in Elisabethville, where he worked for the post office. ${ }^{32}$ Giacomo Macola has documented the continued tension between Kanyembo and UNIP as the

28 Miles Larmer, Marja Hinfelaar, Bizeck J. Phiri, Lyn Schumaker, and Morris Szeftel, "Introduction: Narratives of Nationhood," Journal of Southern African Studies 40, 5 (2014): 895-905, 895-96.

29 Gerald L. Caplan, The Elites of Barotseland, 1878-1969: A Political History of Zambia's Western Province (Berkeley: University of California Press, 1970).

${ }^{30}$ L. J. Butler, "Britain, the United States, and the Demise of the Central African Federation, 1959-63," Journal of Imperial and Commonwealth History 28, 3 (2000), 131-51.

31 Miles Larmer, Rethinking African Politics: A History of Opposition in Zambia (Farnham: Ashgate, 2011), 36-43. The name "Cha Cha Cha" derived from the song "Independence Cha Cha" that celebrated Congolese independence: this was one manifestation of the cross-border dynamics of Central African nationalism.

32 “Chief Kazembe Holds Talks with Tshombe," African Mail, 17 Apr. 1962; D. M. Gordon, "The Cultural Politics of a Traditional Ceremony: Mutomboko and the Performance of History on the Luapula (Zambia)," Comparative Studies in Society and History 46, 1 (2007): 63-83. 
former demanded clarification of the meaning of Zambian independence and stressed the contingent nature of Luapulans' loyalty to the party's nationbuilding project, couched in demands for rapid social and economic development in general and the provision of employment in particular. ${ }^{33}$ Kanyembo's angry opposition to the undermining of chiefly authority by the UNIP's new elected rural councils led him to seek aid from Tshombe in 1965 during the latter's period as Congolese Prime Minister. ${ }^{34}$

As Macola explains elsewhere, the NRANC had significant links with Tshombe, with Nkumbula and party officials regularly visiting Elisabethville during the secession and receiving financial and logistical support. ${ }^{35}$ UNIP denounced these links which, the African Mail alleged, were not only financial, but also involved the recruitment and training of "ANC soldiers" for the Katangese armed forces. ${ }^{36}$ Tshombe thus presented a threat to unitary Zambian nationhood as he did that of Congo: he periodically highlighted the precolonial unity of cross-border societies such as the Lunda and Bemba, for example in his July 1962 claim that "before the Europeans came Katanga and Rhodesia formed one vast territory." 37 Meanwhile, the rulers of the autonomous Barotse Kingdom, strongly opposed to incorporation into a centralized Zambian state, campaigned for continued autonomy or outright independence, angering UNIP leaders. ${ }^{38}$ The risk of Zambia's "balkanization" was considered a major threat, and as the Federation broke up, various schemes were envisioned-by NRANC leaders, Federal politicians, and Britain's Secretary of State for the Colonies Duncan Sandys - for redrawing the borders of Northern Rhodesia. ${ }^{39}$ All such initiatives were seen as an existential threat to UNIP's vision of Zambian nationhood. As the party emerged victorious in the (occasionally violent) struggle with the NRANC to take power at independence, it characterized its political opponents as everything it was not-conservative, tribalist, and localist in orientation - and therefore as unpatriotic according to its definition of Zambian nationalism. ${ }^{40}$ Victory was thus about much more than party political competition-it won for UNIP the power to define Zambia as a nation.

\footnotetext{
33 Giacomo Macola, “'It Means We Are Excluded from the Good Freedom': Thwarted Expectations of Independence in the Luapula Province of Zambia, 1964-67," Journal of African History 47, 1 (2006): 43-56.

34 Ibid.," 53-54.

35 Macola, Liberal Nationalism in Central Africa, 84-87.

36 "ANC 'Soldiers' in Katanga?" African Mail, 8 May 1962. See also "ANC Soldiers in Katanga," African Mail, 31 July 1962.

37 "ANC Soldiers in Katanga," African Mail, 31 July 1962.

38 Caplan, Elites of Barotseland, 190-210; J. Hogan, "'What then Happened to Our Eden?': The Long History of Lozi Secessionism, 1890-2013," Journal of Southern African Studies 40, 5 (2014): 907-24, 911-15.

39 Hughes, "Fighting for White Rule"; Larmer, "At the Crossroads."

40 Macola, Liberal Nationalism, 73-94.
} 
However, UNIP leaders were not in general given to a considered, overtly intellectual approach to the question of national identity. Compared to the generations of literate African intellectuals who debated issues of identity and citizenship in parts of south and west Africa, or the many east African societies in which societal identities were forged by indigenous intellectuals via innovative forms of public writing, the quality and quantity of indigenous reflections on what it meant to be Zambian were limited. ${ }^{41}$ Compared to neighboring Tanganyika, Zambia lacked an indigenous language newspaper publishing industry, except that sponsored by mining companies and the state. ${ }^{42}$ Harri Englund explains the reasons for "the relatively late development of print culture in colonial Zambia": comparatively low education levels, the small Indian business community which elsewhere sponsored the newspaper industry, the colony's low and scattered rural population, and male migration to jobs in Southern Rhodesia. ${ }^{43}$ Englund examines the brief flourishing of government-sponsored African newspapers in Northern Rhodesia in the 1950s and early 1960s and shows that correspondents were primarily concerned not with anti-colonial nationalism, but rather with questions of race and gender relations and wider possibilities of social change.

In comparison, self-consciously nationalist writing was a relatively isolated and extraverted affair, directed at and partly shaped by Western interlocutors such as Colin Morris. ${ }^{44}$ Kaunda's "Humanist" philosophy was itself in some respects a facsimile of Julius Nyerere's ujamaa socialism. Gordon, however, argues that Humanism, partly because of its generalities, made it open to reinterpretation by a range of actors, as Hunter has argued for ujamaa. ${ }^{45}$ During the run-up to independence, in the territory's newspapers and its own publications, UNIP officials sought to characterize the new nation-in-the-making with reference to the tenets of Humanism.

One of the ways that leaders sought to define the Zambian national character was in comparison to the country's neighbors. For Kaunda, whose slogan "One Zambia, One Nation" was as a result of UNIP's electoral success elevated to the new national coat of arms, Zambian values centered on the unity of humankind and a spiritually minded rejection of racial and ethnic divisions. This was contrasted to the situation in Southern Rhodesia to the south,

\footnotetext{
${ }^{41}$ Karin Barber, ed., Africa's Hidden Histories: Everyday Literacy and the Making of the Self (Bloomington: Indiana University Press, 2006); Peterson, Ethnic Patriotism.

${ }^{42}$ Emma Hunter, Political Thought and the Public Sphere in Tanzania: Freedom, Democracy and Citizenship in the Era of Decolonization (Cambridge: Cambridge University Press, 2015).

${ }^{43}$ Harri Englund, "Anti-Anti Colonialism: Vernacular Press and Emergent Possibilities in Colonial Zambia," Comparative Studies in Society and History 51, 1 (2015): 221-47, 226.

${ }^{44}$ Kenneth D. Kaunda, Humanism in Zambia and a Guide to Its Implementation (Lusaka: Zambia Information Services, 1968); Kenneth D. Kaunda, A Humanist in Africa: Letters to Colin Morris from Kenneth Kaunda, President of Zambia (London: Longmans Green, 1966).

${ }^{45}$ David M. Gordon, Invisible Agents: Spirits in a Central African History (Athens: Ohio University Press, 2012), 176-77.
} 
Portuguese-ruled Angola to the west and Mozambique to the east, and Congo to the north. In January 1965, for example, a mass rally heard Kaunda explain "that our society in Zambia shall be non-tribal, non-racial, and that our society in Zambia shall judge each and every individual according to his behaviour."46 Kaunda went on:

Brethren, we need not go very far from here to find out what happens to people who defy God, when people start pointing their fingers at each other because of their tribe and because of their colour. The Congo is a very bad example, because people refused to respect God's creation.... Look what is happening there-innocent men and women and children of all tribes, of all races, are dying every minute.... We don't rejoice that such things happen in the Congo ... The task of building a nation cannot be and is not an easy one.... This is how we intend to go forward as one nation in Zambia. There are no two ways about it.... There must be one nation only in this big country of Zambia. ${ }^{47}$

UNIP supporters drew on the experience of conflict in independent Congo to warn of the dangers of disunity in soon-to-be independent Zambia. For example, in December 1960, the Lusaka-based "Barotse Anti-Secession Association" declared in its bulletin: "We warn the British Government that a seceded Barotseland would only introduce chaos and discord in a settling-down Northern Rhodesia.... The Katanga secession from the Congo incurred an indelible scandal on the reputation of Africa. With the threatened Barotse secession, it would be much worse here." 48

An editorial in the UNIP publication The People's Voice in October 1962 argued: "Daughters and sons of the soil this is the moment when people of all races should formulate their true patriotism by backing the only political party which is not only capable of avoiding another Katanga, but also of bringing peacefull $[s i c]$ political and economic evolution. Remember it is only by uniting as one Nation and combining our resources and efforts that we can uproot this evil prevelant [sic] in our midst." Congo was also invoked to justify UNIP's intolerant attitude toward multi-party democracy. In November 1962, its Deputy National Treasurer Nalumino Mundia, in a story headlined "Let's Prevent Congo Situation," told the African Mail: "To vote for small parties just for the sake of seeing opposition in the Legislative Council will be committing political suicide. Such an act ... will only help to create a fluid Congo-like situation and in that event, we will be jumping from the frying pan into the fire." 49

A key attribute of UNIP's proto-national philosophy was an emphasis on rurality as a norm of African (in general) and Zambian (in particular) identity.

\footnotetext{
46 Kenneth Kaunda, "Mobilizing a Nation," in Zambia: Independence and Beyond: The Speeches of Kenneth Kaunda (London: Thomas Nelson, 1966), 204.

47 Ibid., 205.

48 "Barotse Grumbles Growing," African Mail, 27 Dec. 1960.

49 “Let's Prevent Congo Situation,” African Mail, 6 Sept. 1962.
} 
Although UNIP was, as noted, a mainly urban party, Kaunda (like Nyerere) romanticized a mythic rural precolonial Africa, warned that urbanization would encourage materialism and class divisions, and promoted a "back to the land" policy for Zambian youths. In September 1963, for example, Kaunda addressed an industrial relations course on the subject of social security:

People in agriculture, for instance, are not usually in fear of starvation-even a bad crop will often give them enough to provide substance for themselves and their families. But when a man and his family are dependent on a weekly wage which may suddenly be curtailed by sickness or age, then they need a system to protect them against the worst evils. In our villages or tribal systems we have always had a system of social security with relatives looking after their own in time of need. ${ }^{50}$

This complemented Kaunda's hostility to materialism and consumption associated with new urban societies, notions that underpinned UNIP's growing enmity toward the Copperbelt's labor movement and its propensity for industrial action. ${ }^{51}$ UNIP emphasized that independence would be a period of hard work and sacrifice, and the slogan "sweat before sweet" was regularly deployed in its publications. As will be seen, fear of uncontrolled urban settlement and of the dangerous materialism and immoralities associated with it, and the desirability of village belonging, were articulated by Zambia's new diplomatic representatives in various ways.

The application of contested moral notions to Zambian nation-making and the role of Humanism in that process is strikingly revealed in David Gordon's analysis of the Lumpa church, which challenged UNIP's attempts to impose political hegemony over proto-national territory in the run-up to independence. ${ }^{52}$ UNIP perceived the villages built by the Lumpa church, led by the prophetess Alice Lenshina, as a challenge to its authority, itself undergirded by religiously informed notions of transformation. ${ }^{53}$ Two thousand Northern Rhodesian troops were deployed to destroy Lumpa communities, operations in which about 650 church members were killed. UNIP leaders justified this violent repression by characterizing Lumpa supporters as religious fanatics who had embarked on an "uprising." In his address to the National Assembly, Kaunda described the event as a "national tragedy" in typically Humanist terms: "We have prided ourselves in the past that there was, comparatively speaking, less bloodshed here during the struggle than in many other places in the world where similar struggles have taken place. Lenshina, however, has for her own selfish reasons, left a blot on our record, and it will be a long time before we can erase it.... All my understanding of true religious

${ }^{50}$ Kenneth Kaunda, "People Rather than Plans," in Zambia: Independence and Beyond: The Speeches of Kenneth Kaunda (London: Thomas Nelson, 1966), 21.

${ }_{51}^{51}$ Miles Larmer, Mineworkers in Zambia (London: I. B. Tauris, 2007), 38-40.

52 Gordon, Invisible Agents, 145-167.

53 Ibid., 152. 
groups is that they base their teaching on human love, but in dealing with the problem of Lenshina.... We were, in fact, dealing with not only fanatics, but lunatics." $" 54$ Despite Lenshina's detention, her church still presented such a moral threat to the new Zambian nation at the moment of its birth that it had to remove itself, settling - at the invitation of then Congolese Prime Minister Tshombe-across the border in Mokambo, forming new Lumpa communities that by the mid-1960s had grown to fifteen to twenty thousand people. ${ }^{55}$

Underlying the ostensibly tolerant tenets of Zambian Humanism, then, was a distinctly authoritarian morality that sought to impose a centralized national order - defined in significant part in opposition to the country's neighbors - on diverse and often mobile cross-border societies that had their own morally constituted approaches to the imminent imposition of nationhood. Its professed inclusivity tended in practice to exclude autonomous groups such as the Lumpa church that refused to participate in UNIP's nation-building project. Nonetheless, Zambia Humanism left significant room for the initiatives of the party's and state's own diplomatic actors as they sought to implement national identity through their words and actions. These initiatives are chronicled in the archives of both the Zambian state and UNIP itself, on which this article draws.

UNIP NATIONALISM IN KATANGA, 1963-1964

With the ending of the Katangese secession in January 1963, UNIP, then the dominant nationalist party in a territory on the road to independence, established a party office in the former secessionist capital of Elisabethville. The party sought by such means to project abroad a proto-state under its authority, in ways that bear comparison to the activities of nationalist movements that, as Peterson has shown for East Africa, advanced their claims to independence through the performance of state-like bureaucracies. ${ }^{56}$

UNIP's head of foreign affairs, Simon Kapwepwe, spelled out the party's longstanding opposition to the secession to the Congolese Resident Minister in Katanga in March 1963: "The UNIP will soon be in complete control of Northern Rhodesia (Zambia) and are anxious to establish [a] good neighborly relationship with the Congo.... Kenneth Kaunda believes that the Katangese people will be better off if they are part and parcel of the Congo." ${ }^{, 57}$ UNIP's support for Congolese unity reflected its efforts to impose a coherent national

\footnotetext{
54 Kenneth Kaunda, Zambia: Independence and Beyond: The Speeches of Kenneth Kaunda (London: Thomas Nelson, 1966), 107.

55 Gordon, Invisible Agents, 163.

56 D. R. Peterson, "States of Mind: Political History and the Rwenzururu Kingdom in Western Uganda," in D. R. Peterson and G. Macola, eds., Recasting the Past: History Writing and Political Work in Modern Africa (Athens: Ohio University Press, 2009), 171-90.

57 UNIP Archives (hereafter UNIPA) file 9.1.66, “Congo General, 1963," Simon Kapwepwe to Joseph Ileo, 29 Mar. 1963.
} 
identity within its own borders, including in pro-NRANC areas that did not always share its definition of what it meant to be Zambian. Thus its leaders' expressions of sympathy with Congo's difficulties were simultaneously an assertion of UNIP's unitary vision of Zambian nationalism and a rejection of Nkumbula's federal notions of political authority. ${ }^{58}$ UNIP National Secretary Mainza Chona accordingly wrote to the party's new Elisabethville representative, Jairos Kalsilira, in April 1963: "We hope that sooner or later all our Katangese brothers and sisters will come to know that UNIP has been, is and will always be the champion of their rights. This we can swear and history will help us. We can never adopt a policy prejudicial to our blood relatives over the border. Our aim is unity in the Congo - which is the only way of ensuring peace and progress in any country." 59

Kalsilira, who was not a senior party figure, opened the new office in Elisabethville the following month. Its primary role was to encourage Katanga's many "Zambian" residents to register as voters in the country's preindependence elections, to be held in January 1964. Kalsilira and UNIP were well aware that many such Zambians were sympathetic to Nkumbula's NRANC. Yet Kalsilira was alarmed to discover both the extent of continued support for the secession, particularly among civil servants and those of the Lunda and Sanga "tribes," and the continued activities of NRANC supporters in Katanga. In May 1963, Kalsilira met with Tshombe, who was then (briefly) head of a South Katanga provincial government. Tshombe claimed to want friendly relations with Kaunda who he had, he maintained, helped "during [the 1962 Zambian] Election by my admission that he was not a communist and that he was a reverend's son." 60 In June, Tshombe, accused of having maintained a private militia, fled to Paris and then Madrid, from where he continued to maneuver to re-establish the secession. ${ }^{61}$

Kalsilira was optimistic that stronger border controls would reduce opposition political activity in both countries: "...we shall urge [officials] to apply severe check-up on persons leaving and entering the two countries as to what party they belonged. The move shall neutralize the zone ... [and we will then carry out] an intensive propaganda campaign concentrated on breaking the remnants of secession here and sabotage in Zambia." ${ }^{\text {" }} 2$ This propaganda campaign was to be bolstered by Voice of UNIP radio programs, to be broadcast on weekends from Elisabethville into Zambia from November 1963 onwards. In February 1964 the UNIP office appealed to the party's Secretary for PanAfrican Affairs for additional resources, including a tape-recorder and transport

58 Macola, Liberal Nationalism.

59 UNIPA 9.1.66, Mainza Chona to Jairos Kalisilira, 23 Apr. 1963.

60 UNIPA 9.1.66, “Zambia News Bulletin,” Elisabethville, 22 May 1963.

61 Colvin, Rise and Fall, 143-50.

62 UNIPA 9.1.66, Kalsilira to Chona, 24 Apr. 1963. 
costs: "I am working very hard to [reach] those Lunda people who think that Tshombe will form [the] Lunda Empire... I want to get some speeches from all Luunda Chiefs in North Western Province and put their speeches on air in Congo so that all Luunda in Congo can forget Mr. Nkumbula...."63

UNIP's attempts to reach out to Congolese chiefly authorities were not always well received. In June 1963, a UNIP delegation visited the Lamba Chief Katanga to establish links with Northern Rhodesians resident in his area: "From the outset the chief assumed the air of non cooperative [sic] and returned our greetings with frigidity ... he barked, '... this is my country and I cannot accept any nonsense ... I know UNIP is bad. When I went to witness the coronation of Chief Kazembe, I found all the bridges had been burnt by UNIPs.... UNIPs are bad and can be likened to Watch Towers.' ... If UNIP want to operate their must $[\mathrm{sic}]$ go to their own country or to big cities like Elisabethville or Jadotville but not in his area."64

In response, the UNIP representatives "emphasised that being a Chief of [the] Lamba tribe, he was also our chief and that since the colonial boundaries are only artificial, we are all members of the family who were unfortunately separated from each other by colonial powers to facilitate their ruling over us." ${ }^{\prime \prime}$ By such a discourse, officials of UNIP, a party that generally downplayed the political validity of chiefly authority and ethnic identity, articulated an ethnically centered denial of the basis of (post)colonial statehood when the need arose.

As noted above, Katanga remained insecure: Kalsilira shared the Congolese government's concern about the free movement of former Katangese soldiers, as well as the presence of Central African Federation troops on the Congolese border. ${ }^{66}$ He continually appealed to Lusaka to supply him with additional resources, including money, vehicles and office furnishings, to facilitate "propaganda efforts." ${ }^{, 67}$ Kalsilira organized UNIP branches in Katangahe claimed roughly a thousand individual members in April 1963-and sought to ensure membership fees were used to fund its operations. ${ }^{68}$

However, the UNIP office found itself dealing with cases of "Zambians" (the country did not yet officially exist) being detained because they lacked

63 UNIPA 9.1.103, J. Muhandu to UNIP Secretary for Pan African Affairs Lusaka, 3 Feb. 1964.

64 UNIPA 9.1.78, "Report of Delegates to Katanga," 13 June 1963. Chief Katanga's comparison was between UNIP's Cha Cha Cha activities and the millenarian Watch Tower church. For the latter, see Karen Fields, Revival and Rebellion. Nicole Eggers has more recently conducted research on "Kitawala," the Congolese variant of Watch Tower: "Mukombozi and the Monganga: The Violence of Healing in the 1944 Kitawalist Uprising," Africa 85, 3 (2015): 417-36.

65 UNIPA 9.1.78, "Report of Delegates to Katanga."

66 “Katanga Gangs Start Terror," Central African Mail, 2 Mar. 1963; UNIPA 9.1.66, Kalsilira to UNIP Director of Foreign Affairs Lusaka, 30 Oct. 1963. For more on the aftermath of the secession, see Kennes and Larmer, Katangese Gendarmes, 61-66.

${ }^{67}$ UNIPA 9.1.66, Kalsilira to UNIP National Secretary Lusaka, 24 Apr. 1963.

68 Ibid. 
valid identity documents. In so doing, it took up a de facto diplomatic role, making representation on their behalf to Congolese ministers. ${ }^{69}$ Kalsilira signed some of his reports "Diplomatic Representative" and used "official" paper headed "UNIP Diplomatic Bureau," though in fact diplomatic authority continued to reside with the British Consulate. The UNIP office also liaised with regional liberation movements with offices in Elisabethville, such as Holden Roberto's National Front for the Liberation of Angola (FNLA). A letter of introduction was presented by Jorge Valentin of the Revolutionary Government of Angola in Exile (GRAE) in October $1963 .^{70}$ Kalsilira worked alongside Valentine Musakanya of the consulate in assisting SWAPO leader Kenneth Abrahams, along with other Namibian "refugees," en route to Tanzania. ${ }^{71}$

The shadow of the secession was continually cast on UNIP operations in Elisabethville. For example, an applicant for a position with the party proudly declared: "I speak both English and French fluently, I passed my form IV in Chikuni College [in Northern Rhodesia] in May 1960. I came back to Congo where I worked for two years as a private Secretary to the former President of Katanga, Mr. TSHOMBE Moise. I could not continue with such work due to the fact that this Country was on [sic] war with the United Nations.",72 Such inter-colonial life stories were common, complicating attempts to establish Zambian national identity among a populace that had sought to take advantage of opportunities on both sides of the border for more than half a century.

In this context, some local political leaders envisaged the abolition or redrawing of the border itself, with the region's mining industries underwriting the socioeconomic development of new imagined communities. This narrative was articulated by some NRANC leaders, including former mineworkers' union president Lawrence Katilungu in his talks with Tshombe. ${ }^{73}$ Chama Chakomboka, a Katanga-based Zambian, established in 1963 an organization seeking to establish a "Re-United States of Central Africa" (Re-USCA). Chakomboka explained to the UNIP that Re-USCA, which he claimed had seven thousand members, looked "after the interests and rights of Zambians in Katanga." I4 Its constitution declared as its aim: "To restore and survival [sic] an old nation on Central Africa, into a new strong nation.... To re-identify with our brothers, after a length of artificial separation ... imposed by the colonial ... powers." 75 Chakomboka looked forward to registering Re-USCA in

69 UNIPA 9.1.66, “Zambia News Bulletin,” Elisabethville, 22 May 1963.

70 UNIPA 9.1.66, Jorge Valentin, Feuille de Route No. 4, 31 Oct. 1963.

71 UNIPA 9.1.66, Kalisilira to UNIP Director of Foreign Affairs Lusaka, 24 Oct. 1963.

72 UNIPA 9.1.78, “Elizabethville, 1963," Bwalya J. wa-Lombe to UNIP National Secretary Lusaka, 17 Sept. 1963.

${ }^{73}$ Larmer, At the Crossroads, 13.

74 UNIPA 9.1.78, Chama Chakomboka to UNIP National Secretary Lusaka, 3 Oct. 1963.

75 UNIPA 9.1.78, Re-United States of Central Africa Constitution, n.d. 
Zambia and hoped to stand as a UNIP candidate. UNIP's National Secretary Mainza Chona remained unconvinced, and he asked Chakomboka rhetorically: "Which States do you want to re-unite and which unions do you want to dissolve in Central Africa? Which country and nation existed before the advent of colonial rule ... which you want to re-assimilate ... which 'old nation on Central Africa' do you want to restore?"76

Chona was understandably suspicious of the irredentist potential of Re-USCA, reflecting as it did an important strand in Copperbelt political culture, namely the desire to abolish the colonial border and (re)unite local ethnicities into a new state incorporating as yet undetermined territories in Congo and soon-to-be independent Zambia. Chakomboka nonetheless did become UNIP's acting Regional Secretary in Elisabethville and would continue to advocate the creation of the United States of Central Africa until at least the early 1980 s. $^{77}$

In its public statements, and in line with Kaunda's discourse (as quoted above), the UNIP office contrasted Congo's negative experience of "tribal" political conflict with the unified nationalism to be seen in Northern Rhodesia. Whereas Katangese parties-Jason Sendwe's Cartel and Tshombe's Conakatwere established on explicitly ethnic grounds, Nkumbula's NRANC had, Kalsilira asserted, been rejected by Zambian voters because of "petty human weakness" rather than "tribal" factors. Kalsilira emphasized that Zambians had generously welcomed the Katangese "exodus" during the 1960-1961 crisis, which "was received with open arms of friendship and love; so many today remark of how wonderfully welcome they were amongst us." ${ }^{, 78}$ Likewise, in preparation for the Northern Rhodesian elections of January 1964, UNIP instructed its radio broadcasters: “Appeal to voters' sense of reason rather than to their emotional, sectional or tribal propensities. Show them the need for building a national identity in which all other divisions disappear. We must create a sense of national unity and belonging. Instil [sic] a feeling of confidence in the listener's mind so that he has faith in our activities."

Despite its efforts to promote national unity, UNIP's Katanga office was itself beset by rivalry and denunciations, of Kalsilira, and by him of his colleagues. These specifically focused on corruption and failure to complete tasks, but were often articulated as accusations of "tribal grouping." ${ }^{80}$ Attempts to establish a sense of unified national belonging were undermined by claims of

\footnotetext{
76 UNIPA 9.1.66, UNIP National Secretary Mainza Chona to Chama Chakomboka, 24 Oct. 1963.

7 Larmer, Rethinking African Politics, 217-18.

78 UNIPA 9.1.66, UNIP Diplomatic Representative Bureau, Press Release, 21 July 1963.

79 UNIPA 9.1.66, A. B. Masiye to UNIP Representative Elisabethville, 11 Nov. 1963.

${ }^{80}$ UNIPA 9.1.66, Kalsilira to UNIP Secretary for Pan African Affairs Lusaka, 8 Jan. 1964; UNIPA 9.1.103, Deputy National Secretary A. Milner to UNIP Congo Republic Representative, 18 Jan. 1964.
} 
ethnic favoritism. Kalsilira also warned of "Elements who wanted to [dis]guise themselves as UNIP members ... for membership cards and letters of party introduction, but would turnout $[$ sic $]$ to be:- a. either dangerous to the national interest ... [or] b. Loafers who wanted infiltration to zambia [sic] thereafter pretend to be in destitute for cash...."

In the months before Zambian independence, the office was beset with tensions over money and the sale of party membership cards, with one official claiming in June 1964 that Chakomboka "is employed without the party's knowledge," that the owner of the UNIP office was owed 9,000 Francs, and that the office had been closed without notice. ${ }^{82}$ Despite efforts to integrate Zambian residents of Katanga into Zambian politics, some of them claimed they had been denied the right to vote in the January 1964 elections. Indeed, one group petitioned the Congolese authorities for the right to participate in that country's Constitutional Commission ${ }^{83}$ on the basis of their cross-border migrant identities and an assertion of precolonial unity:

We shall respect all of us what will come out of the Constitution after accepting us as real congolease [sic] citizens:

Among us there [are] some people whose sons were born here.

Among us there are many people who got pensioned in the Congo and don't think of going back to Rhodesia. Therefore they remain here in large cities or farming in the customary areas, and die right here.

For a long time congolease and Rhodesian peoples ... married and thier [sic] sons are recognized as congolease. For these we ask that all parents and all children are recognized as true Congolese citizens.

Don't forget that all of us are from the same family. The colonialist[s] are responsible for some divisions that exist because in [the] past we had lived together. ${ }^{84}$

UNIP representative Kalsilira, though, noted that among the signatories to this petition was Bunda Chisenga, the NRANC representative in Katanga. ${ }^{85}$ Kalsilira rejected the claim that they had been denied the right to vote: "Provision was made for people in a foreign country to vote on condition that the[ir] period of absence from N.R. was less than 12 months, and were genuine Zambians." 86 Kalsilira claimed the petition was an NRANC initiative to "buy" votes in both Katanga and Zambia in the future. Underlying the positions of all sides to this dispute was the contested basis of what it meant to be Congolese, Zambian, or both.

${ }^{81}$ UNIPA 9.1.103, J. D. Kalsilira, "UNIP Central Committee Members Alone," 13 Jan. 1964.

${ }^{82}$ UNIPA 9.1.103, "Elisabethville UNIP office, 1964-66," Kipushi Constituency Secretary Yesaya Kaira to Administrative Secretary UNIP Lusaka, 25 June 1964.

${ }^{83}$ CRISP, Congo 1963 (Brussels: CRISP, 1964), 386-95.

${ }^{84}$ UNIPA 9.1.103, "Elisabethville UNIP office, 1964-66," "Petition to the Delegates of the Constitutional Committee [sic-Commission]," Luluabourg, 3 Feb. 1964.

85 Macola, Liberal Nationalism, 190.

${ }^{86}$ UNIPA 9.1.103, "Elisabethville UNIP office, 1964-66," Kalsilira to UNIP Director for Foreign Affairs, 3 Feb. 1964. 
Zambia became independent on 24 October 1964 and rapidly established diplomatic representation in a number of countries. Its foreign policy during the First Republic (1964-1972) has been widely analyzed with regard to its prominent position in diplomatic efforts to resolve southern Africa's regional liberation movements. ${ }^{87}$ Most such studies, which document President Kaunda's dominance of foreign policy, say little about the role of the country's embassies and tend to approach the topic from a realist, institutional perspective. None examine the autonomous role of Zambia's embassies or draw on the insights of the new diplomatic history by approaching diplomacy from the perspective of individual actors and the social interactions of overseas diplomats. Yet it is clear that, as this section will explain, the country's new diplomats in Congo, when confronted with incidents involving new Zambian citizens, responded to them in distinctly cultural ways that projected their sense of national values, rooted in a moralistic reading of what it meant to be Zambian.

Alongside its new embassy in the capital Leopoldville (later Kinshasa), Zambia's only regional consulate anywhere in the world was established in Elisabethville (later Lubumbashi). The new Zambian authorities appreciated, as had their colonial predecessors, the strategic and economic importance of Katanga and its mining industry, and, in contrast to the UNIP office, they staffed both institutions with prominent figures. The first ambassador, Timothy Kankasa, was a former trade union leader who had served as VicePresident of the Northern Rhodesian Trade Union Congress shortly before his diplomatic appointment. He subsequently served as Minister of State for Foreign Affairs, as a Copperbelt MP, and in the 1970s as a junior minister for Land and then Labour. Wilson Chakulya, the Elisabethville-based Consul, had likewise established his credentials as a pro-UNIP loyalist, first in Broken Hill (later Kabwe) and then in the Copperbelt labor movement. He went on to serve as General Secretary of the Zambia Congress of Trade Unions, and from 1971 as Minister of Labour, roles in which he sought to cement party and government control over the country's unions. ${ }^{88}$

Both men observed and-in reports to the new Foreign Ministry in Lusaka - commented on the continued tumult of Congolese politics. ${ }^{89}$ Given the UNIP's hostility to the secession, it is striking that both Kankasa and Chakulya, as well as Zambia's observers of Congo's 1965 elections, reported:

\footnotetext{
87 Timothy M. Shaw, "The Foreign Policy of Zambia: An Events Analysis of a New State," Comparative Political Studies, 11, 2 (1978): 181-209; Douglas G. Anglin and Timothy M. Shaw, Zambia's Foreign Policy: Studies in Diplomacy and Dependence (Boulder: Westview Press, 1979); Andy DeRoche, Kenneth Kaunda, the United States and Southern Africa (London: Bloomsbury, 2016).

${ }^{88}$ Larmer, Mineworkers in Zambia, 64-84.

89 CRISP, Congo 1965 (Brussels: CRISP, 1966); CRISP, Congo 1966 (Brussels: CRISP, 1967).
} 
“...it appeared to us that Tshombe was the only person at present who seems to enjoy [the] popularity of the people.... He and [Godefroid] Munongo are the only Ministers in the present government who had dared to visit each and every province in the Congo, regardless of the danger to their personal safety." 90

One unresolved legacy of colonialism was the still partial demarcation of the border between the two countries, access across which remained disputed. The Congolese pedicle that intruded into Zambia, itself the peculiar legacy of colonial border-drawing, had long proven hazardous for Zambians moving between their Copperbelt residencies and their areas of origin in what were now Zambia's Northern and Luapula provinces. ${ }^{91}$ Two decades of periodic negotiations between British and Belgian officials had failed to resolve rights of access to, or security on, the Pedicle Road. ${ }^{92}$ Mwelwa Musambachime has documented the ubiquity of violent harassment of Northern Rhodesian migrants, and showed how during the Katangese secession and following Zambian independence there was a rise in instances of petty theft and demands for bribes and violence, particularly by poorly paid Congolese soldiers. ${ }^{93}$ In the years after independence, the Pedicle Road remained a hazardous crossing, where currency was stolen by Congolese nationals and goods were extorted by Congolese immigration and customs officials from Zambian travelers, who never seemed to have exactly the right documentation. ${ }^{94}$

\section{FORMALIZING CROSS-BORDER LAW AND DISORDER}

A key aspect of Bourdieu's notion of "codification" is the "formalization" of societal categories and practices by the classification of that which is particularly ambiguous and disordered: "To codify means to banish the effect of vagueness and indeterminacy, boundaries, which are badly drawn and divisions which are only approximate, by producing clear classes and making clear cuts, establishing firm frontiers, even if this means eliminating people who are neither fish nor fowl. Difficulties in coding ... force one to reflect on those

90 National Archives of Zambia (hereafter NAZ), Ministry of Foreign Affairs (hereafter MFA), file 1/1/40, "Kinshasa Reports," 1966. Godefroid Munongo was Minister of the Interior in the Katangese secessionist government and served under Tshombe in his Congolese government during this period.

91 Martin W. Lewis, "The Congo Pedicle and Its Challenges to Zambian Development" (2011): http://www.geocurrents.info/economic-geography/the-congo-pedicle-and-its-challenges-to-zambiandevelopment (accessed 3 Apr. 2017).

92 NAZ, MFA 1/1/3, “Zambia-Congo Boundary, 1958-1968," Senior Provincial Commissioner Ndola to Secretary for Native Affairs, Lusaka, 27 Oct. 1958.

93 Mwelwa C. Musambachime, "Military Violence against Civilians: The Case of the Congolese and Zairean Military in the Pedicle 1890-1988," International Journal of African Historical Studies 23, 4 (1990): 643-64, 663.

94 NAZ, MFA 1/1/3, “Zambia-Congo Boundary, 1958-1968," various reports 1966 and 1967. 
unclassifiable members of our societies ... those creatures who are indeterminate from the point of view of the dominant division." 95

The nationalization of the (post)colonial border prompted Zambian diplomats to attempt to codify people who had worked and raised families on both sides of it. National independence in theory necessitated the settling of one's citizenship, but Copperbelt residents continued to make identities and form relationships that resisted such stabilization. Northern Rhodesian men had worked in the Katangese mines since the turn of the century and, although the Congolese mining company Union Minière had sought to employ mainly Congolese workers from the 1930s onward, in practice many "Northern Rhodesians" continued to work in Congolese mines. Although exact figures are unavailable, between 1954 and 1958 around 7.5 percent of Union Minière's African workforce, some twenty-five thousand-strong, was classified as "foreign"- that is, not Congolese, Rwandan, or Burundian-and it is likely that the vast majority of these were Northern Rhodesians. ${ }^{96}$ Some had married women from Congo, with whom many shared "ethnic" identities and language and who they clearly did not regard as "foreign," a concept of questionable meaning in the closely connected urban milieu of the cross-border Copperbelt. The fixing of one's national identity was arguably economically irrational in an environment where wages and conditions of service varied considerably over time in different mines, among different employers, and between the two territories. National independence, however shone a harsher bureaucratic light in its efforts to resolve such ambiguities.

In 1966, that light shone on Peter Fwalanga. A veteran mineworker at Zambia's Rhokana mine, Fwalanga had retired to Congo during the late colonial period. He resided in Lubumbashi, but visited Zambia each month to collect his pension of $£ 45$, which he changed into Congolese Francs in the Zambian town of Mufulira shortly before crossing back into Congo. On this occasion however, his money was seized by customs officials, who explained that he had been contravening regulations for many years, since the export of currency was illegal in both countries. ${ }^{97}$ Greater sympathy was expressed for Terese Tshilema, fifty-seven, a Congolese national settled in the Zambian city of Kitwe for twenty-seven years. On seeking to return to Congo with her property converted into cash and watches, Tshilema had her entire assets seized by Zambian customs officials. The Congolese Embassy in Lusaka appealed to the Zambian Ministry of Foreign Affairs for lenience: "Being old and ignorant, she would not think of going through proper and legal channels before proceeding with the transfer and the exportation of her property....

\footnotetext{
95 Bourdieu, “Codification," 82 (his emphasis).

96 UMHK Archives, Brussels, box 658, Département de MOI, Annual Report 1958.

97 NAZ, MFA 1/1/24, "Zambia Missions Congo, 1964-68," Permanent Secretary MFA to Controller of Customs and Excise, 6 Sept. 1966.
} 
One may be compelled to believe that the sum of $£ 200$ represents the whole of this old woman's fortune. It should be taken into account that the old woman had to work very hard and for quite a long time to have such a fortune." 98 While national independence imposed stringent controls over financial movements, senior Zambian officials expressed disquiet about the limited presence of immigration authorities, where only " 11 Officers 'cover' a range of 120 miles of the most sensitive part of the Congo border where it is closest to the Copperbelt." 99 Such comments reflected the continued limited capacity of the state, particularly in a sensitive and strategic border region.

As well as financial irregularities, consul officials concerned themselves with what they regarded as cross-border moral irregularities. In 1966, the Consul approached the District Secretary for Bancroft (on the Zambian Copperbelt) regarding Lubumbashi resident Samuel Musotolwa, whose wife of twentyfive years had left him caring for ten children while she went on "leave" for two months. Musotolwa believed that his wife had become "illegally married" to one Mwape Kalusa, formerly of Lubumbashi but now resident in Bancroft. The new Consul W.K.C. Kamwana sought prompt but unspecified action against the export of Congolese immorality to Zambia: "As it is not our wish to encourage people to make Zambia as [a] hiding place for such mischievous immorals which are Part and Parcel of their lives here, we shall ... be praised if such kind of behaviour could be stamped out completely." ${ }^{100}$ Kamwana subsequently reported a second case of spousal abandonment by a wife now resident in Zambia: the woman's father was as a result interviewed by a Zambian state official in Ndola, to whom he gave assurances that his daughter would return to her husband. ${ }^{101}$ Kamwana was troubled by the increasing mobility and independence of Zambian women since independence and reflected nostalgically on the colonial way of handling such problems: "When the British looked after the interests of the now Zambians the system used to be that of sending those involved in [the] dispute to their home areas when the relatives of both parties were consulted before a decision was reached.... But since we became independent Zambians are finding it hard to maintain their homes, in most cases, women ... [are] ... being induced by other men ... against their husbands and ... corrupting those in authority in order to gain a favour ... most of the women get away with it."102

98 NAZ, MFA 1/1/24, “Zambia Missions Congo, 1964-68,” DRC Embassy Lusaka to Ministry of Foreign Affairs, 31 Mar. 1967.

99 NAZ, MFA 1/1/3, "Zambia-Congo Boundary, 1958-68," Permanent Secretary Ministry of Home Affairs to Secretary to Cabinet, 7 July 1965.

${ }^{100}$ NAZ, MFA 1/1/24, “Zambia Missions Congo, 1964-68," W.K.C. Kamwana to District Secretary for Bancroft, 6 Apr. 1966.

${ }^{101}$ NAZ, MFA 1/1/24, "Zambia Missions Congo, 1964-68," W.K.C. Kamwana to Permanent Secretary MFA, 8 Mar. 1967, "Zambian Marriage and Divorce Problems."

102 Ibid. 
Kamwana bemoaned the inability of Congolese courts to handle such cases and sought guidance on current Zambian marriage law, effectively seeking to position himself as the authority on cross-border marital disputes. The preceding year, Consul Wilson Chakulya had likewise noted that his British colonial predecessor had practiced a system of "tribal" representation for Zambians in Katanga; older men long resident in Katanga, regarded as custodians of custom, were employed to guide their "tribesmen" in instances of social conflict. ${ }^{103}$ The use of such tribally based representation was opposed by UNIP and had indeed been abolished in Northern Rhodesian mines in 1953 following a ballot of mineworkers instigated by the African Mineworkers' Union. ${ }^{104}$ More than a decade later, the Zambian Consul concluded that the reintroduction of such "traditions" would help Zambia regain the support of its Katangese residents whose loyalties, he regretfully noted, had been extended to Tshombe. ${ }^{105}$ The Consulate was faced with the disconnection between potential diaspora tribal representatives and their "home" chiefs in what had, since their departure, become "Zambia." As a result its officials struggled to give culturally informed advice to aid the resolution of, for example, matrimonial disputes. Neither could they look to the Congolese courts for adjudication since there was in them an "absence of the knowledge of Zambian Customary Law."106 Ambassador Kankasa, however, rejected any such recognition of customary authority and, in line with UNIP ideology, the "tribalism" it was thought to constitute. He nonetheless recommended: "That negotiations be entered into with the Congolese Government as a matter of urgency; so as to facilitate posting of Zambian Court assessors to Katanga to deal with cases of Customary Law in nature and that these assessors be attached to Katangese Law Courts. After all Bemba or Lunda Customary Law is not different in Katanga to that in Zambia."

Zambia's Ministry of Foreign Affairs rejected both proposals and it appears no such intervention was carried out, but this debate shows that political independence did not immediately resolve the tension between "modern" and "customary" law, generating as a result the concept of "Zambian customary law," which was oxymoronic since nation-state and "tribal" customary laws were supposedly separate legal spheres.

103 NAZ, MFA 1/1/24, "Zambia Missions Congo, 1964-68," Zam Consul General Chakulya to Permanent Secretary MFA, 28 June 1965.

104 A. L. Epstein, Politics in an Urban African Community (Manchester: Manchester University Press 1973 [1958]), 14-17.

105 NAZ, MFA 1/1/24, “Zambia Missions Congo, 1964-68," Zam Consul General Chakulya to Permanent Secretary MFA, 28 June 1965.

106 NAZ, MFA 1/1/24, “Zambia Missions Congo, 1964-68," Zam Consul General Chakulya, 12 July 1965

107 NAZ, MFA 1/1/24, “Zambia Missions Congo, 1964-68,” T. J. Kankasa to Permanent Secretary MFA, 5 Aug. 1965. 


\section{CITIZENS AND STRANGERS}

The greatest challenge for Zambia's new diplomats arose from the Congolese/ Zairian state's increasing assertion of a more rigid definition of citizenship. As in many other postcolonial African states, this was driven by attempts to impose clear definitions of citizenship on mobile populations with evidently mixed origins, a particularly problematic process in areas where "national" identities were a recent creation and where cross-border mobility was central to people's social identity. In some cases, as Manby and also Dorman, Hammett, and Nugent have shown, citizenship rules were deliberately rewritten to exclude political opponents of independent governments and/or to scapegoat certain ethnicities. ${ }^{108}$ As Manby rightly states, “...many African governments treated marginal populations with suspicion, regarding their loyalty as especially suspect when their kith and kin were dominant in a neighbouring state."109 This tendency arguably became more common as time went on, but Mobutu's Congo was a pioneer in such practices, and Katanga provided one of its first testing grounds.

Zambia, in contrast, maintained relatively inclusive citizenship laws throughout the period of UNIP rule (1964-1991), whilst opponents of President Kaunda-from the ANC in the early 1960s through to the United Progressive Party (UPP) of the early 1970s and the Movement for Multi-party Democracy (MMD) in the 1990s - argued that his Malawian parentage should have excluded him from office. ${ }^{110}$ UNIP nonetheless deployed a discursive Humanistic notion of national identity with the aim of managing those at the margins: to be Zambian was to identify with a fixed rural place of origin; to stress collective endeavor over individual success; to participate in collective "nation-building" activities initiated by the UNIP-dominated state; to cooperate with one's neighbors; and to be prepared to sacrifice in the national interest. Apparent refusal to live up to these national values invited retribution. It is noteworthy that in 1967 Kaunda wrote to Mobutu calling for either the repatriation of Mokambo-based Lumpa church members to Zambia or their relocation away from the border into the Congolese interior. The continued presence of Lenshina's followers in exile provided a powerful cross-border riposte to UNIP's supposedly inclusive participatory nationalism. ${ }^{11}$

108 Dorman, Hammett, and Nugent, Making Nations; B. Manby, Struggles for Citizenship in Africa (London: Zed Books, 2009).

109 Manby, Struggles for Citizenship, 31.

110 Macola, Liberal Nationalism, 88-99; Larmer, Rethinking African Politics, 83-84; Manby, Struggles for Citizenship, 129-32.

111 David M. Gordon, "Rebellion or Massacre? The UNIP-Lumpa Conflict Revisited," in Jan-Bart Gewald, Marja Hinfelaar, and Giacomo Macola, eds., One Zambia, Many Histories (Leiden: Brill, 2008), 45-76, 74. 
In the context of this study, these sharply contrasting approaches to nationmaking were applied in a context where, as noted, many people who were now defined as "Zambian" residents had been employed by the Katangese state itself and remained in sympathy with the quiescent but not extinguished secessionist project. In the mid-to-late 1960s, Tshombe continued to maneuver for a second return from exile, Katanga was treated by the Mobutu regime as occupied enemy territory, and tensions between former Katangese forces and the wider Congolese National Army manifested in a mutiny in July-October 1967. ${ }^{112}$ During this period, Mobutu dramatically centralized power, giving himself the authority to rule by decree, and he had Tshombe tried in absentia for instigating the mutiny.

In October 1965, all civil servants in Congo's Katanga Orientale province were ordered to take Congolese citizenship by the end of the year or face dismissal from employment. Zambian Consul Chakulya helped some individuals renounce their Zambian citizenship in order to retain their posts, for example one Augustin Cesar Kathundu, born in Kolwezi in the Belgian Congo in 1942 but described as a subject of Chief Kakoma in Zambia's Mwinilunga District. ${ }^{113}$ In 1967, President Mobutu announced new regulations that ostensibly clarified who was, and who was not, a citizen. This was an unashamedly patriarchal initiative since those with Congolese mothers but Zambian fathers suddenly discovered they were non-citizens. This disproportionately affected thousands of Katanga's residents, many of whom were born in Congo and had never visited Northern Rhodesia, yet were now forced to claim Zambian citizenship. Many of these turned to the Zambian Consulate for help. Some individuals faced the contradiction of inconsistent definitions of citizenship: Jean Mathew Kahutu, born in Belgian Congo in 1943 to Zambian parents, had been briefly employed by the newly established Zambian Airways in Lusaka, but had then been fired and subsequently deported for being Congolese. His Congolese identity card was marked with a red cross used to identify foreigners and he now faced the prospect of statelessness as a result of the "Congolization" policy. ${ }^{114}$

In April 1967, the new Consul E. M. Mwamba explained to Zambia's Minister of Education that he had been approached by

... a number of teachers who are Zambian nationals, but [who] have been living in the Congo some for many years and most know no English but only French and Bemba, etc. They expressed to me their anxiety on the future, because of the present Congolese Central Government trend to dismiss thousands of Katangese Civil Servants and those Zambian Nationals who have been working as policemen. Already 6,000 civil

112 CRISP, Congo 1966, 365-75; Kennes and Larmer, Katangese Gendarmes, 75-79.

113 NAZ, MFA 1/1/24, "Zambia Missions Congo, 1964-68," Declaration of Renunciation of Zambian Citizenship, 12 Apr. 1966.

114 NAZ, MFA 1/1/24, “Zambia Missions Congo, 1964-68," W.K.C. Kamwana to MFA, 13 Oct. 1967. 
servants who were employed after 1960 independence have been dismissed, while about over 600 Zambians who have been working even before independence have been dismissed. $^{115}$

Mwamba claimed that some 250,000 Zambians were in Congo, for whom there were no alternative forms of employment, and he asked what Zambia might do for them. Zambian officials observed that the crisis had politically sensitive origins, namely in the mutiny of three thousand "Katangese" soldiers in Kisangani (see above), of whom "about 1,000 are Zambians or can claim Zambian citizenship by descent." 116 The dismissal of secession-era civil servants was now extended to all those who under the new citizenship laws were classified as Zambians: "[T]he Central Government's wrath against the Zambian residents stems from tribal connections between Zambians and the majority of the tribes in Katanga, and also from the fact that Katangese Zambians were staunch supporters of Mr. Moise Tshombe, and many of them saw active service or lost their brothers and sons in the Katanga secession wars.",117

In October, a list was compiled of eighty-seven Zambians dismissed from the Congolese police force. ${ }^{118}$ The Copperbelt Labour Commissioner noted that many of the 250,000 identified had always lived in Congo and saw it as their home, but were in danger of destitution there. Zambia thus faced the danger of these destitute people - unable to bring Congolese savings with them-crossing into its economically strategic Copperbelt mining towns, with implications for national security. ${ }^{119}$ By November 1967, ninety-three "repatriates" had indeed taken up residence at a Zambia Youth Service camp in Kitwe. Some were retrenched mineworkers who had arrived with the erroneous belief that they would be given jobs in Zambian mines, an impression they claimed was based on promises made by Mwamba's predecessor Kamwana. ${ }^{120}$

Zambia's state officials interpreted these problems in different ways. It is noteworthy that the Kinshasa-based Ambassador Kankasa largely accepted the Congolese state's position regarding Katangese dissent, which dovetailed closely with the UNIP's own unitary vision of nation-statehood. In January 1968, for example, Kankasa praised Mobutu's imposition of military control:

115 NAZ, MFA 1/1/144, “Zambian Nationals in the Congo 1966-67,” E. M. Mwamba, Consul General Lubumbashi to Mwanakatwe, Ministry of Education, 20 April 1967.

116 NAZ, MFA 1/1/144, "Zambian Nationals in the Congo 1966-67," S. K. Bwalya, Assistant Labour Commissioner, n.d. (ca. 7 June 1967), "Dismissal of Zambians Working in Katanga of the Congo Republic."

117 Ibid.

118 NAZ, MFA 1/1/24, “Zambia Missions Congo, 1964-68,” n.d., Oct. 1967, list of eighty-seven names.

119 NAZ, MFA 1/1/144, "Zambian Nationals in the Congo 1966-67," S. K. Bwalya, Assistant Labour Commissioner, n.d. (ca. 7 June 1967), "Dismissal of Zambians Working in Katanga of the Congo Republic"; NAZ, MFA 1/1/24, “Zambia Missions Congo, 1964-68," Acting Regional Secretary Western Province R. S. Thompson to Permanent Secretary, MFA, 13 Nov. 1967.

120 NAZ, MFA 1/1/144, "Zambian Nationals in the Congo 1966-67," meeting, 17 Nov. 1967. 
"It would appear at the moment that the Congo needs a man like General Mobutu who will dictate, backed by force, and there is no doubt that the country is already on the road to unity and national consciousness." 121 Congo was not, Kankasa believed, a country that could afford more than one political party. ${ }^{122}$ In contrast, the Elisabethville-based Consul Mwamba expressed sympathy with not only dispossessed "Zambians," but also the wider Katangese community of which they were a part. When dismissed Katangese political appointees fled to Zambia following the 1967 abolition of its provincial government, Mwamba warned against their involuntary return: “...the handing over of Katangese to the Congolese Central Government would be viewed by [the] Katangese population including several hundred thousands of Zambians who are residents in Katanga as a complete sell out of Katanga to Southern, Central, [and] Eastern Congolese politicians who dominate the Mobutu Government. What should be known in Zambia is that over 300,000 Zambians who live in Katanga feel to have the same interests with the Katangese with whom they are identified." 123

Zambia's response to this crisis revealed the various ways in which national citizenship and belonging were being imagined. In general, no effort was made to challenge or reject the redrawing of Congolese citizenship laws and Zambia accepted the considerable burden of these new nationals without complaint. Officials did, however, seek to manage their mobility and activities in ways that demonstrated that being Zambian involved certain forms of behavior. Such morally informed notions arose in relation to the question of resettlement: what would it mean for these people to move "back" to Zambia? Most were long-term urban residents, but authorities were acutely aware of their state's inability to provide for the Zambian Copperbelt's rapidly growing population, and had incorporated Kaunda's idealized notion of rurally driven national identity and development. Discussion of the resettlement of these new Zambians thus focused on a "return" to migrants' supposed rural areas of origin, with urban residence, as in the colonial era, reserved for those with gainful formal employment. In July 1967, the Ministry of Labour's J. B. Nyirongo argued against special treatment for "repatriates": “...Zambian citizens who are being repatriated from the Congo should, where possible, be persuaded to go straight to their villages where they will be able to leave their wives and children, and if they desire to get employment they could apply for it through their District Secretaries. In this way, only those persons who receive offers of employment would be expected to come to the line of rail... The advantage of

121 NAZ, MFA 1/1/140, “Kinshasa Reports, 1966," Ambassador Kankasa to Minister of Foreign Affairs Reuben Kamanga, Report no. 1, 1-15 Jan. 1968.

122 Ibid.

123 NAZ, MFA 1/1/237, "Refugees from the Congo, 1967-1968," Lubumbashi Consul General E. M. Mwamba to MFA Simon Kapwepwe, 5 July 1967. 
this is that there would be no repatriates and their families stranded on the Copperbelt, as would appear to be the case now."124 It should be emphasized that most such "citizens" had never visited the villages to which they were now to be "returned." Such policies dovetailed with UNIP's general attempts to discourage rural-to-urban migration and its idealization of rural residents as quintessential Zambians.

Alongside opportunities for employment, access to education was the focus of many cross-border claimants. In August 1965, the consulate was approached by three young Zambians brought up in Congo: they had registered as Congolese and had successfully secured government scholarships, but then discovered that these required them to work for the Congolese government after graduation. $^{125}$ Unwilling to do so, they instead sought scholarships from Zambia. Similar ambitions were articulated by Henry Katongo, in an appeal to the consul in October 1967 following the closure of Congo's universities as a result of political upheaval:

Being a Zambian National, I did my primary and secondary schools here in ... Lubumbashi. I have just completed my secondary school and did register myself at the Official University of the Congo but the Congolese Government did not want to grant me a bursary because I'm a Zambian. I have therefore decided to pay personally 6.000 francs per annum for my university school fees, it is not extraordinary. But ... I later heard that the three universities of the Congo were closed. Therefore what am I going to do?... I still need to learn, and I'm not prepared to begin working. And at last I see only one chance for me, and that is to ask for a Zambian scholarship, the bursary which will enable me to continue with my studies in a francophone university.... Either in France, Swiss, Germany, Belgium and so forth.... It's my last recourse because I now seem to be abandoned, rejected by the Congo ... also I don't think I may [be] sent away by my proper country which is Zambia the one I can help after I have completed my schooling. ${ }^{126}$

Katongo's request was summarily rejected by Consul Chakulya, who declared: "I have little sympathy for such people." "127 Such individualistic claims betrayed the collective spirit of Zambian Humanism. They did, however, reveal the basic problem that such "Zambians" commonly spoke and sometimes wrote French (and various African languages), but not English, the language of the Zambian state. Ambassador Kankasa sought to resolve this problem by the establishment of a Zambian state school in the Congolese

\footnotetext{
124 NAZ, MFA 1/1/24, “Zambia Missions Congo, 1964-68," Permanent Secretary, Ministry of Labour J. B. Nyirongo to Assistant Labour Commissioner Ndola, n.d., July 1967.

125 NAZ, MFA 1/1/24, “Zambia Missions Congo, 1964-68," Consul General Chakulya to Permanent Secretary Ministry of Education, 26 Aug. 1965.

126 NAZ, MFA 1/1/24, "Zambia Missions Congo, 1964-68," Henry Katongo to Consul General Lubumbashi, 13 Oct. 1967.

127 NAZ, MFA 1/1/24, "Zambia Missions Congo, 1964-68," Zam Consul General Chakulya to Permanent Secretary Ministry of Education, 26 Aug. 1965.
} 
border town of Kipushi, a project he discussed with President Kaunda during the latter's visit to the Copperbelt in March $1968 .{ }^{128}$ The envisaged school would provide instruction in English and teach the Zambian curriculum. ${ }^{129}$ Consul Kamwana encouraged Zambian residents of Katanga to form committees and to fundraise for the planned school, to adopt a "self-help" approach, and to refrain from both tribalism and involvement in Congolese politics, thereby exhibiting their characteristics as good Zambians. In a speech to announce this scheme, Kamwana sought to iron out the contradictions in such a project, but only exemplified them: he agreed with the Congolese District Commissioner that the problem was that "some of our ... subjects kept on changing from place to place, however the reason [is] that the tribes found in the Congo are also found in Zambia, therefore to them the borders are but formalities only.... While protecting our Nationals we all know that territorial integrity of each state must be fully respected for this is the fundamental foundation of peace and ... sound brotherly relations." ${ }^{\prime 30}$ Because of a lack of Zambian state resources to pay for the proposed school, every Zambian in Congo, Kamwana declared, should pay one Zaire (the Congolese currency) to pay for the school, which would be named after the Zambian president Kenneth Kaunda. ${ }^{131}$

\section{CONCLUSION}

There is no evidence that the Kenneth Kaunda school was ever built in Zaire, and it seems unlikely that most of the expelled "Zambians" ever left the country. The Mobutu state's capacity for issuing numerous decrees was matched only by its inability to enforce them. Such state initiatives, in seeking to enforce a particular notion of Congolese national identity, did, however, prompt Zambian state officials to articulate a specific form of Zambian national identity defined in considerable part in opposition to it. National unity should be encouraged, but it should be the result of a natural communitarian affiliation to a nation, not an individual, instrumentalist choice based on self-interest, the antithesis of Humanism. People should be citizens of only one nation, but this was, Zambian diplomats recognized, difficult to achieve in a border region where nationalities could not be easily

\footnotetext{
128 NAZ, MFA, 1/1/140, “Kinshasa Reports, 1966,” Ambassador Kankasa tour of Katanga, report to MFA Kamanga, 12 Apr. 1968.

129 NAZ, MFA, 1/1/140, "Kinshasa Reports, 1966," Ambassador Kankasa tour of Katanga, report to MFA Kamanga, 15 Feb. 1968.

130 NAZ, MFA 1/1/140, "Kinshasa Reports, 1966," Consul W.K.C. Kamwana tour report, 17 Apr. 1968.

131 Ibid.
} 
distinguished from each other and where people were accustomed to moving across the border.

In seeking to establish the basic functions of modern statehood, and in their responses to the demands made upon them by their problematic cross-border citizens, officials of the newly independent Zambian state grappled with the difficulties of imposing a sense of nationhood on people who saw states as potential providers of resources but who were, it appears, relatively relaxed about their "national" identity and many of whom had supported a secessionist movement at odds with the centralizing nationalism of both countries. If France had once sought to turn "peasants into Frenchmen" via the deployment of transport infrastructure and education, UNIP's efforts to turn residents of both sides of the Copperbelt border into Zambians were limited by a dearth of party and state resources to encourage or enforce such affiliation. ${ }^{132}$ In their place, party officials in general and diplomatic officials in particular articulated morally constituted Humanist notions of appropriate patriotic behavior that emphasized chiefly patriarchy, marital fidelity, and need for a rural area of origin, all of which replicated in a nationalist form a strikingly colonial way of doing things.

Nation-making, it has been argued, thus involved not only the assertion of state sovereignty over fixed territorial space and its populace, and the passing of citizenship laws, but also a much wider process that fundamentally rested on the articulation of the moral and political notions that underpinned them. New state officials presiding over the representation of that state and its subjects abroad necessarily engaged not only the legalization of national identity but also its codification, a process of symbolic ordering closely bound up with morally constructed notions of what it meant to be, in this case, "Zambian." These assertions struggled to make themselves felt in border spaces where a sense of national belonging, identity, or characteristics was still being both created and challenged, where cross-border mobile populations were only just learning to think of themselves as, for example, "Zambian" or "Congolese," and where who did and did not belong to these nations was still being decided. In this context, Zambian officials deployed a set of nationalist discourses constructed in relation to ideational notions of nationhood, "ethnicity," and the historical meaning of precolonial and colonial identities. This constructivist, bricolage approach to nation-making necessarily involved inconsistencies, for example at times denying the political validity of "ethnic" identity while at other times valorizing it as reflective of a precolonial

132 Eugen Weber, Peasants into Frenchmen: The Modernization of Rural France, 1870-1914 (Stanford: Stanford University Press, 1976). 
and thereby authentic form of belonging. Such an approach was entirely consistent with the inconsistent nature of nation-making in early postcolonial Africa.

\begin{abstract}
How and where were new African nations made at the moment of decolonization? Focusing on the periphery rather than the center provides an insightful answer to this question: imposing national identity in border regions with mixed and mobile populations, dynamic migrant flows, and cross-border linkages was a task fraught with contradiction. This article explores the establishment of Zambian political and diplomatic space in the Democratic Republic of Congo and the activities of Zambian political and diplomatic representatives in the southern Congolese city of Elisabethville in the early-to-mid 1960s. It does not assess how effective these officials were in imposing a sense of Zambian national identity, but rather what their efforts reveal about the ideas and values that informed state elites' assertions of national identity and their relationship to history, local identities, and moral codes regarding, among other things, customary authority and gendered behavior. The article argues that nation-making in newly independent states involved the assertion of not only state sovereignty over territorial space but also symbolic power, the right to classify, and the moral and political notions that underlay ostensibly bureaucratic, disinterested state structures. Analysis of the attempts of Zambia's first diplomatic representatives to establish and assert their notion of Zambian-ness reveals the fragility of new national identities and the extent to which elites sought to underpin these identities by the assertion of moral certainties.
\end{abstract}

Key words: nationalism, borders, decolonization, Africa, Zambia, Democratic Republic of Congo, diplomacy 